ACTION: Notice of availability.

SUMMARY: NIOSH announces the availability of the final National Occupational Research Agenda for Public Safety.

DATES: The final document was published March 6, 2019 on the CDC website.

ADDRESSES: The document may be obtained at the following link: https:// www.cdc.gov/nora/councils/pubsaf/ research_agenda.html.

FOR FURTHER INFORMATION CONTACT: Emily Novicki, M.A., M.P.H,

(NORACoordinator@cdc.gov), National Institute for Occupational Safety and Health, Centers for Disease Control and Prevention, Mailstop E-20, 1600 Clifton Road NE, Atlanta, GA 30329, phone (404) 498-2581 (not a toll free number). SUPPLEMENTARY INFORMATION: On April 12, 2018, NIOSH published a request for public review in the Federal Register [83 FR 15838] of the draft version of the National Occupational Research Agenda for Public Safety. All comments received were reviewed and addressed where appropriate.

Dated: March 7, 2019.

Frank J. Hearl,

Chief of Staff, National Institute for

Occupational Safety and Health, Centers for Disease Control and Prevention.

[FR Doc. 2019-04460 Filed 3-11-19; 8:45 am] BILLING CODE 4163-19-P

\section{DEPARTMENT OF HEALTH AND HUMAN SERVICES}

\section{Centers for Disease Control and Prevention}

[Docket Number CDC-2019-0018, NIOSH328]

Draft-National Occupational Research Agenda for Healthy Work Design and Well-being

AGENCY: National Institute for Occupational Safety and Health (NIOSH) of the Centers for Disease Control and Prevention (CDC), Department of Health and Human Services (HHS).

ACTION: Request for comment.

SUMmARY: The National Institute for Occupational Safety and Health of the Centers for Disease Control and Prevention announces the availability of a draft NORA Agenda entitled National Occupational Research Agenda for Healthy Work Design and Well-being for public comment. To view the notice and related materials, visit https:// www.regulations.gov and enter CDC-
2019-0018 in the search field and click "Search."

Table of Contents

- DATES:

- ADDRESSES:

- FOR FURTHER INFORMATION CONTACT:

- SUPPLEMENTARY INFORMATION:

- BACKGROUND:

DATES: Electronic or written comments must be received by May 13, 2019.

ADDRESSES: You may submit comments, identified by CDC-2019-0018 and docket number NIOSH-328, by any of the following methods:

- Federal eRulemaking Portal: https://www.regulations.gov Follow the instructions for submitting comments.

- Mail: National Institute for

Occupational Safety and Health, NIOSH Docket Office, 1090 Tusculum Avenue,

MS C-34, Cincinnati, Ohio 45226-1998.

Instructions: All submissions received in response to this notice must include the agency name and docket number [CDC-2019-0018; NIOSH-328]. All relevant comments received will be posted without change to https:// www.regulations.gov, including any personal information provided. For access to the docket to read background documents or comments received, go to https://www.regulations.gov. All information received in response to this notice will also be available for public examination and copying at the NIOSH Docket Office, 1150 Tusculum Avenue, Room 155, Cincinnati, OH 45226-1998. FOR FURTHER INFORMATION CONTACT: Emily Novicki, M.A., M.P.H., (NORACoordinator@cdc.gov), National Institute for Occupational Safety and Health, Centers for Disease Control and Prevention, Mailstop E-20, 1600 Clifton Road NE, Atlanta, GA 30329, phone (404) 498-2581 (not a toll free number). SUPPLEMENTARY INFORMATION: The National Occupational Research Agenda (NORA) is a partnership program created to stimulate innovative research and improved workplace practices. The national agenda is developed and implemented through the NORA sector and cross-sector councils. Each council develops and maintains an agenda for its sector or cross-sector.

Background: The National Occupational Research Agenda for Healthy Work Design and Well-being is intended to identify the research, information, and actions most urgently needed to prevent occupational injuries. This research agenda provides a vehicle for stakeholders to describe the most relevant issues, gaps, and safety and health needs for the sector. Each NORA research agenda is meant to guide or promote high priority research efforts on a national level, conducted by various entities, including: Government, higher education, and the private sector.

This is the first Healthy Work Design and Well-Being Agenda, developed for the third decade of NORA (2016-2026). It was developed considering new information about injuries and illnesses, the state of the science, and the probability that new information and approaches will make a difference. As the steward of the NORA process, NIOSH invites comments on the draft National Occupational Research Agenda for Healthy Work Design and Well-Being. Comments expressing support or with specific

recommendations to improve the agenda are requested. A copy of the draft agenda is available at https:// www.regulations.gov (see Docket Number CDC-2019-0018).

Dated: March 7, 2019.

Frank J. Hearl,

Chief of Staff, National Institute for Occupational Safety and Health, Centers for Disease Control and Prevention.

[FR Doc. 2019-04498 Filed 3-11-19; 8:45 am] BILLING CODE 4163-19-P

\section{DEPARTMENT OF HEALTH AND HUMAN SERVICES}

\section{Centers for Medicare \& Medicaid Services}

[Document Identifier CMS-10325]

Agency Information Collection Activities: Submission for OMB Review; Comment Request

AGENCY: Centers for Medicare \& Medicaid Services, HHS.

ACTION: Notice.

SUMmARY: The Centers for Medicare \& Medicaid Services (CMS) is announcing an opportunity for the public to comment on CMS' intention to collect information from the public. Under the Paperwork Reduction Act of 1995 (PRA), federal agencies are required to publish notice in the Federal Register concerning each proposed collection of information, including each proposed extension or reinstatement of an existing collection of information, and to allow a second opportunity for public comment on the notice. Interested persons are invited to send comments regarding the burden estimate or any other aspect of this collection of information, including the necessity and utility of the proposed information collection for the proper performance of the agency's functions, the accuracy of the estimated burden, ways to enhance 